\title{
Controversy and Conversation: The Relationship Between the Humanities and the Sciences
}

\subsection{INTRODUCTION}

This chapter examines the relationship between the humanities and the sciences, which is a connection that has become particularly significant in the context of contemporary valuation of higher education. The British Academy report "Past, Present, and Future: The Public Value of the Humanities and Social Sciences" (2010) identified the "tendency to see STEM subjects as the key to the success of universities and to national economic recovery" (2010, 3 my italics). The present division between Science, Technology, Engineering, and Mathematics subjects (STEM) and the arts, humanities and social sciences (HASS henceforth) is made explicit in government policy. It is concerning to observe the ways in which government policy is shaping the cultures of valuation and ultimately encouraging a shift in the significance of specific disciplines within higher education.

The debate over value between the sciences and the humanities has, in different guises, been taking place since the beginning of scholarly debate. In retracing the conversations between the disciplines, this chapter underlines how "[humanities] scholars and scientists share more, and have a greater interest in common where the role of universities is concerned, than the hackneyed contrast tends to suggest" (Collini 2012, 101). There are many more than two perspectives and approaches to knowing, despite the stereotypical binary of humanities versus sciences. However, within a

Z. H. Bulaitis, Value and the Humanities, Palgrave Studies in Literature, Culture and Economics, https://doi.org/10.1007/978-3-030-37892-9_3 
complex field of disciplinary practices, concentrating on this binary opposition allows for something meaningful to be articulated. The present preference for science over the humanities is not timeless. As the two cultures debate illustrates, some sixty-five years ago, science was in a defensive position. Therefore, the purpose of this chapter is to document how value has previously been articulated when the humanities and the sciences came into public confrontation. The discussion moves from the present backward through historical debates: Section 3.2 explores the present policydefined distinctions between the disciplines; Section 3.3 interrogates the two cultures debate between Charles P. Snow and Frank R. Leavis in the 1960s; Section 3.4 revives the correspondences between Matthew Arnold and Thomas H. Huxley. Taking a longer view of the connection between STEM and HASS can open up a series of conversations with more productive and open-ended results. Re-contextualising the present value crisis scholars face, at the level of national governance and funding, this chapter explores how the humanities and the sciences have previously negotiated tensions between their disciplines. Focusing on past debates draws attention to useful discursive tools as well as a reassurance that the current myopic perspective of policymaking is not destined for permanence. A narrative history reveals that such declarations of disciplinary difference were announced between the arts and the sciences, not about them. Therefore, this chapter offers an articulation of the value of the humanities that is not presented as a justification to policy but as an example of the active processes of understanding that are inherent in the disciplines themselves.

\subsection{Part I: Policy and the Relationship Between THE DisCIPLINES}

\subsubsection{Present Policy Preferences}

The discussion in Chap. 2 demonstrated the prioritisation of economic skills within the Browne Report in the funding bias towards STEM subjects, in terms of grants for undergraduate tuition. The removal of block grants, as a consequence of the policymaking decision to "withdraw public investment through HEFCE from many courses to contribute to wider reductions in public spending" (Browne 2010, 25), has impacted the arts and humanities to a greater extent than the sciences. Writing in The Telegraph, 20 February 2011, Simon Schama observes how "sciences and 
subjects which seem to be on a utilitarian measure useful have retained their state funding while the arts and humanities are being stripped of theirs" (2011). STEM subjects are seen to be able to produce economically beneficial discoveries. The Browne Report recognises that "the costs of these courses are high and, if students were asked to meet all of the costs, there is a risk that they would choose to study cheaper courses instead" $(2010,25)$. Despite the privatisation of tuition fees and the adoption of a free market of education, there is nonetheless "public investment to support priority courses and the wider benefits they create" (25). Therefore, this is not a free market of education, but rather a marketplace with specific incentives and sponsorship from the state. Such delineation between disciplines has caused concern amongst humanities scholars, who argue that their work has been sidelined as less valuable than the work of their colleagues in the sciences.

In terms of research funding, a preference towards metric evaluation has led to further concern. Speaking about the UK context in 2008, Martha Nussbaum observed how "the current Labour government [had] recast all research, including humanities research, on the model of research in the sciences" $(2010,128)$. The remodelling of research assessment frameworks in 2008 saw the application of categories used to assess science and innovation also used to justify value in the humanities. The Independent Review of the Research Excellence Framework, known as the Stern Review, published its assessment of the 2014 REF in July 2016. The report "Building on Success and Learning from Experience" summarises how the reforms between 2008 and 2016 aspired towards a "metrics-based, target-driven exercise" (Stern 2016, 42) that would "better demonstrate and incentivise the economic and societal contribution, and justify continued investment in, public funding for Science \& Research" (42). Introduction of impact metrics into the 2014 Research Excellence Framework further altered the valuation of research, the implications of which are directly addressed in Chap. 5. To briefly encapsulate the relevance of these changes to the present discussion: policymakers were dubious that "the peer review based system was as effective and efficient as it could be" (Stern 2016, 42). Changes to research assessment have introduced a new policy landscape which, most commonly, recognises value when presented in metric form. Many researchers within the humanities argued that a quantitative approach to research assessment favours STEM subjects which are more naturally inclined to produce data and evidence-based results. 
The valuation of tangible results is evidenced across the higher education sector, from marketing campaigns, to funding allocations, to module design. ${ }^{1}$ For example, a promotional video "A Year in the Life of the University of Exeter" published on YouTube, 12 December 2013, celebrates that year's research across the university. It exhibits a heavy bias towards the sciences: of the eight examples demonstrated in the video seven are the consequence of STEM research (University of Exeter 2013a). The lone contribution from the humanities, an Archaeology project, explains "Buoyant Bronze Age Boat Makes History in Cornwall". ${ }^{2}$

This singular humanities example is the exception that proves the rule. Archaeologists worked alongside the National Maritime Museum to reconstruct a working bronze-age boat using original materials and techniques. The projects celebrated in the video all provide clear tangible results and each idea is communicated with fewer than ten words. The subtitles provide further insight into the domination of results: "scientists prove", "scientists get", and scientific "study uncovers". The video pronounces the creation of " 350 jobs" and celebrates breaking into the "Top 150 World Ranking" (2013a) for universities worldwide. Numerical results, economic profits, and tangibility of research outcomes become indicators of a successful year in higher education. This poses a problem for the humanities since not many scholars are able (or, significantly, willing) to balance research and teaching with shipbuilding. Although this example is hyperbolic, the demand for tangible and marketable values leads to the funding of projects that can be readily defined in quantitative terms.

The above discussion is not a debate about the value of the humanities and the sciences, instead, it is an indication of how the marketing of higher education and the white papers of Parliament value the kinds of research that science produces, as well as the graduates that it creates. In From Two Cultures to No Culture: C.P. Snow's 'Two Cultures' Lecture Fifty Years On Frank Furedi et al. describe how in the contemporary period "questions about the role of the sciences and of the humanities in education seldom acquire the form of a debate about substance. Increasingly, concerns about the intellectual content of education have given way to narrow technical

\footnotetext{
${ }^{1}$ See John Guillory (1993) Cultural Capital: The Problem of Literary Canon Formation for a critique of the "technobureaucratic conditions" (264) of curriculum design.

${ }^{2}$ See promotional video on the University of Exeter's YouTube page or read the associated news coverage "Buoyant Bronze Age Boat Makes History in Cornwall" (University of Exeter 2013b).
} 
ones about the organisation of the curriculum" $(2009,64)$. In terms of both scope and scale-the defence of an entire mode of thinking-returning to genuine conflict in the two cultures debate provides a point of contrast to higher education today. Furedi et al. highlight how "in 1959 Snow worried about divisions between the two cultures; we now have to ask ourselves whether our culture can survive, in any meaningful sense, at all" $(2009,25)$. The melodrama of such a claim clearly fits in with the allure of crisis narratives, discussed in the introductory chapter. However, the monoculture of market value is a serious concern for both scientists and humanities scholars alike. Furedi et al. are correct in identifying that today it is not the scientist and the literature professor who are in direct contest, but, instead, the policymaker and the scholar. This is a novel pairing since historically the dispute concerning value developed between the disciplines. Before turning to specific examples of debate, the following section briefly outlines the nature of this repetitive debate.

\subsubsection{A Brief History of an Age-Old Argument}

Empirical and humanistic forms of knowing provide near-constant counterpoints as ways in which to perceive the world. Patricia Waugh details the repetitious nature of opposition within academic cultures as follows:

in antiquity, an emergent rationalism vied with a literary culture concerned with the training of the orator-lawyer; in the Renaissance, an emergent humanism with an entrenched Scholasticism, the foundation of a theological training and world-view; since the 19th century, the cultures of the humanities have found themselves repeatedly clashing with the positivist or rationalistic foundations of the research model of scientific training. $(2009,308)$

All of the above exchanges are disputes or conversations amongst scholars themselves. Helen Small's The Value of the Humanities makes a similar reference to the repetitive nature of debates such as these. She identifies how "Sokal was a repetition of Snow/Leavis; Snow/Leavis of Huxley/ Arnold; but the deeper historical roots go back into classical antiquity" $(2013,37) .^{3}$ Repetition does not make the debate any less significant, in

${ }^{3}$ The Sokal affair was a publishing hoax in which Alan Sokal, Professor of Physics at New York University (NYU), published an article "Transgressing the Boundaries: Towards a Transformative Hermeneutics of Quantum Gravity" (1996) in leading cultural journal Social 
fact, Small argues that returning to moments of conflict can provide a lens through which to more clearly distinguish disciplinary forms. The reinterpretation of scholarly history is an important part of the work that humanities scholars do. With this in mind, this chapter follows a similar genealogy to Small in tracing the relationships of Snow and Leavis before returning to Huxley and Arnold. Small observes how in debates concerning the sciences and the humanities all repetitions are different,

but they share two positive features: a recognition of the rhetorical power of binary oppositions; and a provisional commitment to their utility as diagrammatic accounts of the educational field as it encounters the political field. They crudify matters, but they also clarify them, and when faced with complexity we may be persuaded to put up with quite a lot of crudeness in the service of getting a basic outline from which refinements can start. $(2013,37)$

Operating through hyperbole, these debates are able to capture a crude caricature of the values that are at stake in the work of the humanities. In “C. P. Snow's Fiction of Two Cultures" Peter Stringer argues that “simplifying and ordering properties help to make sense in particular of complex, large-scale and troubling phenomena" $(1983,172)$. The problem facing the humanities and the sciences today is surely complex and troubling. Small's idea of crudeness in repetition provides the benefit of "getting a basic outline" $(2013,37)$ of the relationship between the humanities and the sciences, which appears to be so instrumental in shaping the landscape of value in higher education. Upon this foundation, more advanced speculations can be built.

\subsection{Part II: The “Two Cultures Controversy", Then AND Now}

The infamous debate between C. P. Snow and F. R. Leavis during the 1960s forms this chapter's first example of such an oppositional relationship between the sciences and the humanities. An extensive body of scholarship describes the implications of the two cultures debate and chronicles

Text, before announcing his article was written as a deliberate attempt to unmask the dangers of postmodernism. For discussion see Editors of Lingua Franca, The Sokal Hoax: The Sham That Shook The Academy (2000). 
the contemporaneous critical commentary with equal precision. ${ }^{4}$ As a result, I will not re-tread old ground in the hope revealing a new revelation concerning the content of the exchange between Snow and Leavis. However, returning to this moment of contact between the sciences and the humanities presents an articulation of the humanities in a moment of confident self-valuation, which is in stark contrast to the defensive language commonly deployed in the present moment. This section specifically considers how articulations of value can be established though rhetorical confrontation; the investigation is not a case of who said what when but rather, who said what how. Returning to the exchange between Snow and Leavis provides an opportunity to explore the productive capacities of voicing disciplinary conflict.

The discussion is structured as follows. First, I introduce the specific lectures in which the controversy emerged, exploring the motivations behind and rhetorical structure of both Snow and Leavis' public statements. Second, I outline the continued interest in the two cultures as a defining moment between the humanities and the sciences. Drawing upon the recently re-edited Canto editions of Snow's The Two Cultures and the Scientific Revolution (2012) and Leavis' The Two Cultures? The Significance of C. P. Snow (2013) both introduced by Stefan Collini, I discuss how the lectures represent value through their formal properties. Finally, in drawing upon critical theory concerning opposition and rupture, I argue that the activity of speaking up for values in the form of a public lecture produces a significant social event. The vitality of speech-acts and the opportunities that a public lecture affords is an area of scholarship concerning the "two cultures" that has been underdeveloped. Although Snow and Leavis are dismissive of many aspects of each other's culture, and remain in the realm of oppositional and stereotypical criticisms, reading these avid defences of discipline leaves an audience with little doubt that there are cultures to be preserved.

\footnotetext{
${ }^{4}$ See Trilling, L. (1962) "Science, Literature and Culture: A Comment on the LeavisSnow Controversy"; Kimball, R. (February 1994) “The Two Cultures' today"; Ortolano, G. (2009) The Two Cultures Controversy: Science, Literature and Cultural Politics in Postwar Britain; Furedi et al. (2009) From Two Cultures to No Culture C.P. Snow's 'Two Cultures' Lecture Fifty Years On; Collini, S. (2013) "Leavis v Snow: The Two-Cultures Bust-Up 50 Years On”.
} 


\subsubsection{The Birth of a Controversy}

The Snow-Leavis controversy is perhaps the most regurgitated public debate in the history of modern intellectual life. Such notoriety is, in part, due to the aggressive defences of science and literature that the exchange produced. On 7 May 1959, British scientist and novelist C. P. Snow delivered a lecture that was to make the term "two cultures" famous. ${ }^{5}$ The occasion was the annual Rede Lecture held at Cambridge University and the speech was published as The Two Cultures and the Scientific Revolution later that same year. Snow describes a "gulf of mutual incomprehension" and "lack of understanding" (1959b, 5) between the humanities and the sciences. Throughout the lecture, Snow adopts the term "two cultures" to describe the particular incomprehension between "literary intellectuals" and "physical scientists" (1959b, 4). Despite the narrow focus of Snow's contention, subsequent critical debates, and coverage in the media over the past fifty years has used the two cultures to represent a broader distinction that is made between the study of subjects within the humanities and the sciences as opposed to literature alone. ${ }^{6} \mathrm{Within}$ this more general division of disciplines, the arts and social sciences are often included in the category of humanistic culture (such as SSH or HASS) with scientific culture being comprised of natural sciences, technology, engineering, and mathematics (STEM). ${ }^{7}$ In his recent introduction to The Two Cultures and the Scientific Revolution, Collini observes how Snow "talk[s] about characteristics of research scientists and of writers as groups, and makes no practical proposals for shrinking the gap he identifies between them" (see Snow 1959b, xxvi). The purpose of the lecture was to distinguish one culture above another: literary scholars were to be seen as "selfimpoverished" (Snow 1959b, 14) by their ignorance and traditional value, while scientists "have the future in their bones" (12). Collini notes how the debate that Snow initiated was not "concerned with the structure and content of educational arrangements" (see Snow 1959b, xxvi) but rather with the ideological positioning of disciplines within society at large. For

\footnotetext{
${ }^{5}$ Snow first used the phrase in an article in the New Statesman, 2 October 1956 (Snow 1959a).

${ }^{6}$ The significance of literature (and by association the subject of English) as a representative subject for the humanities is addressed further in Chap. 4, see Sect. 4.3.2.

${ }^{7}$ Kagan, J. (2009) among others, has argued that the social sciences constitute an entirely distinct third culture.
} 
Snow, national progress required "breaking the pattern into which they had crystallised" $(1959 \mathrm{~b}, 40)$ and recognising the value of applied sciences above that of literary culture.

The "two cultures" became the "two cultures controversy" when that "auteur of hauteur" (T. Miller 2007, 45), F. R. Leavis, assumed the task of response. Three years after the Rede Lecture, Snow's assertions about the value of science became one side of an emerging dispute. Leavis used the occasion of the annual lecture at Downing College, Cambridge, 28 February 1962, to deliver his rejoinder to Snow. Although Leavis' lecture addressed the disciplinary differences between literature and science, it was also a direct and personal attack on Snow's authority to speak on the topic. Charlotte Sleigh describes how Leavis "loudly and publicly scoffed at the value of science, and denounced the quality of Snow's novels for good measure" $(2011,3)$. Some of the most acerbic of remarks that Leavis levies against Snow include: "he doesn't know what he means, and he doesn't know he doesn't know" $(1962,55)$; "the intellectual nullity" of "Snow's panoptic pseudocogencies, his parade of a thesis: the mind to be argued with - that is not there" (56); "Snow is, of course, a- no, I can't say that; he isn't; Snow thinks of himself as a novelist" (57). Leavis was unrelentingly sarcastic and authoritative in his dismissal. His lecture argued that Snow grossly misunderstood literary culture and identified how, as a result of the speakers' ignorance, the vision outlined in The Two Cultures and the Scientific Revolution was largely erroneous.

Although Leavis' criticisms were directed at Snow as an individual, it was not the result of any long-standing personal feud. In his lecture, Leavis notes how, at the time of the initial publication of Snow's treatise in 1959, he had "perceived plainly enough what kind of performance the lecture was, and had no inclination to lay down three and sixpence" $(1962,55)$ to purchase the publication in order to give it further scrutiny. His belated response three years later was likely partly fuelled by an irritation that Snow's novels were being used in examination papers to read English at Cambridge. In his lecture, Leavis complains that "sixth-form masters were making their bright boys read Snow as doctrinal, definitive and formative" (56). Leavis remarks with surprise at how "it rapidly took on the standing of a classic" (55) and it was likely the lasting influence of Snow's argument that was the greatest insult to Leavis. The wide circulation and lasting power of Snow's speech, rather than the immediate content, is what caused Leavis to react so strongly. 
Leavis lived and worked in Cambridge for his entire life. The tone of the lecture at a time when one might expect a gracious retirement is a central component of the shock-factor of the confrontation. ${ }^{8}$ Initial reactions to the lecture flooded the letters page of The Spectator. Many were highly critical of the acerbic tone and personal nature of Leavis' speech, for example, in The Spectator, 16 March 1962, Stephen Toulmin argued that it "amounts to an abuse of language" (12); Lord Boothby called it "reptilian venom" (11); and Susan Hill resented the "cheap jibes and highly personal statements" (11-12). Beyond surprise at the anger of the lecture, critics also identified that in his destructive critique, Leavis had offered little articulation of the value of the humanities. Hill commented that "having knocked down C. P. Snow, he presents us with no alternative to Snow-presumably, as he does not, he has none" (The Spectator 1962, 11); Boothby similarly, argued that "there is not a single constructive thought in his lecture; and the Cambridge audience who tittered at his malicious asides, and applauded at the end because they thought it was the right thing to do, should be thoroughly ashamed of themselves" (11). The many affronted respondents to Leavis' lecture reveal the high-stakes in the debate. While Snow's Rede Lecture had been received well at first and had been relatively undisputed, Leavis' lecture opened up a controversy in its first utterance. ${ }^{9}$

Leavis published a transcript of The Two Cultures? The Significance of C. P. Snow in Spectator on 9 March 1962 enabling further circulation and speculation upon the debate. In subsequent reprints of his lecture Leavis stood by his comments about Snow. Much critical attention has been paid, both in contemporaneous and present-day discussions of the Snow-Leavis affair (as it became known), as to how Leavis attacked Snow so personally within the content of his lecture. In the introduction to The Two Cultures: The Significance of C. P. Snow Collini offers an alternative interpretation to the assumptions presented above. He defends Leavis by arguing that "the Richmond lecture has been frequently misperceived as a personal attack on Snow" (see Leavis 1962, 11). Instead, Collini insists that the comments were merely designed to "correct the overestimation of Snow as a

\footnotetext{
${ }^{8}$ Leavis' retirement plans were well-known prior to his Downing lecture.

${ }^{9}$ For evidence of the relative neutrality and broad assent towards Snow's Rede Lecture see Encounter (August 1959) "C. P. Snow and 'The Two Cultures"” responses from Walter Allen, A.C.B. Lovell, J. H. Plumb, David Riesman, Bertrand Russell, Sir John Cockcroft, and Michael Ayrton 67-73; see also Encounter (September 1959) "The Two Cultures" 61-65.
} 
sage" (11). Leavis was increasingly resistant to the relationship between fame and academia, and avoided participating in literary celebrity life that was particularly located in London at the time. As Collini observes how Leavis "despaired of the superficiality and mutual back-scratching of contemporary literary culture" and sought to foster a "university of a minority public capable of true critical discrimination" (see Leavis 1962, 6). Leavis, accordingly, describes Snow as a "portent" who is largely "created by the cultural conditions manifested in his acceptance" $(1962,54)$. Therefore, Collini posits that the central criticism of The Two Cultures and the Scientific Revolution is not directed at Snow, but at the society that has promoted him to such theocratic heights within the academy.

This consideration leads to a wider question: how can an individual critic speak up against a value system? Leavis' answer was through a specific and embodied attack on the rhetorical speech of someone whom he perceived to be a figurehead. Attacking Snow's professional abilities has been remembered infamously in the years following the debate. However, I argue that the form of the argument itself is of use for the contemporary value debates in higher education through paying close analysis to how large-scale systemic values are expressed in a discrete and embodied format, such as a public lecture. The following section explores how the form of the argument of the two cultures controversy has continued to captivate, and questions why no intellectual disagreement has exceeded the scandal of Leavis and Snow in the past half-century.

\subsubsection{The Form of the Debate}

Watching from across the Atlantic, Lionel Trilling, writing for the Higher Education Quarterly, November 1962, observed how "so curious a storm rages in England" (9). Trilling's account provides a concise survey of the two lectures and ensuing correspondences. Significantly, his article concludes with identifying several similarities between Snow and Leavis. He notes that "if ever two men were committed to England, Home and Duty, they are Leavis and Snow-he would say that in this they are as alike as two squares" (27-28). Both men promote what they believe to be the best way to value knowledge within higher education. Therefore, Snow and Leavis provide active performances of the tacit tensions in the academy at that time. Small reports that "observation on the most famous and fractious of two culture encounters" in fact "tells us very little about the kinds of work the participants' university colleagues were doing at the time but a great 
deal about the wider social, cultural, institutional, and political factors that had a bearing on the argument" (see Leavis 1962, 35). These wide institutional and political concerns motivated Snow and Leavis' public lectures to put forward their statements on the matter. It is these wider factors, rather than their individual personalities that maintain the relevance of the debate to our present context.

Frank James argues that "there is a tendency by non-historians to view issues and ideas, such as the Two Cultures, as timeless" (2016, 109). Instead, each manifestation, although repetitive, should be understood as historically contingent. The phrase "two cultures" did not simply appear by coincidence in 1959 but instead provided a name for an already existent phenomenon at a critical moment. Guy Ortolano provides a meticulously researched account of the specific context of post-war Britain and its significance in the emergence of the two cultures debate in The Two Cultures Controversy: Science, Literature and Cultural Politics in Postwar Britain (2009). He argues that "the exchange between Snow and Leavis was one such dispute, one that was charged by - and is revealing of-the context and culture in which it took place" (7). While drawing upon an awareness of the socio-historical context that Ortolano's study provides, I reject his conception of thinking of history as a series of "episode[s]" (9). Both scholarly writing and media coverage of "the two cultures controversy" predominantly focuses on recounting one or two episodes. I want to challenge the idea of the two cultures controversy as an episode in history and instead consider it as a rupture of ideological forces that were long operational beneath the surface. It is a refrain, or a repeating motif, that is expressed in a particular way for a particular reason. As Leavis was well aware, analysis of argumentative style holds disruptive potential. In The Way We Argue Now Amanda Anderson observes, "intellectual and aesthetic postures are always lived practices" $(2006,7)$. The two cultures controversy is a clear example of this, and in enlivening the values they represent, Snow and Leavis offer us distinct academic values to consider.

The speeches of Snow and Leavis as speeches are significant in developing an understanding of the ideological implications of a moment of rupture and the moment of response. Therefore, I will discuss the formal qualities of the events that history has chosen to remember (Ortolano's "episodes"), in order to understand how two academic lectures could have produced so long-lived a debate. I argue that the form of the debate generates value within a particular historical context. Collini observes how "a lecture is above all an occasion, in both senses of the word-it is a social 
event and it is an opportunity" (see Snow 1959b, xxviii). He argues that, in comparison to other forms of argumentation, "the lecture strikes a more declarative or argumentative pose, and even though the best lectures exploit a collusive relation with their audience, the form is inherently pedagogic" (xxviii). A lecture represents an occasion in which language can produce expressions of opinions that endure. The opportunity to discuss disciplinary value was always present; it was simply the "occasion" that brought about the expression in the medium of a pedagogic and polemical lecture. Therefore, a lecture provides a formalised opportunity to express a perspective with the guarantee that the speaker will be heard. Understanding value in these terms is much like Judith Butler's notion of performative agency. ${ }^{10}$ Butler argues that speech acts "bring about certain realities" $(2010,147)$ especially when uttered from those wielding social status. Although, admittedly, "utterance alone does not bring about the day" she argues that it "can set into motion a set of actions that can, under certain felicitous circumstances, bring the day around" (148). Snow delivered his treatise in a public lecture in Cambridge in 1959 and Leavis presented his cutting response to an audience within the same institution three years later. The medium of controversy was born in the lecture hall and continued in newspaper columns and printed responses. These events were not specifically designed for the purpose that the speakers elected to use them for. Two eminent scholars took the opportunity to co-opt the lecture space to represent the values they sought to uphold within the academy. Such coercion of a public event might yet be revived as a strategy for articulating the value of the humanities.

Beyond the basic properties of a lecture, further formal qualities of controversy are also worthy of attention. In bringing oppositional forces into contest, sides are established and polarities are drawn. It was when Leavis responded to Snow, that the two cultures became the two cultures controversy. It is important to distinguish between these two phrases. Richard Rorty notes how "rivalries such as these will doubtless always exist, simply because Hegel was right that only a dialectical agon will produce intellectual novelty" $(2004,28)$. Agonism, the belief that contestation can be a productive force in society, has been explored in the work of Nietzsche, Adorno, and Foucault. Nietzsche's “Homer's Contest" defines the purpose of Agonistic critique as,

\footnotetext{
${ }^{10}$ The term "performativity" develops John L. Austin's idea of "performative utterance". See Austin, J. L., "How to Do Things with Words" $(1962,22)$.
} 
a thought that is hostile to the 'exclusivity' of genius in the modern sense, but assumes that there are always several geniuses to incite each other to action, just as they keep each other within certain limits, too. That is the kernel of the Hellenic idea of competition: it loathes a monopoly of predominance and fears the dangers of this, it desires, as protective measure against genius - a second genius. $(2006,178)$

With the arrival of the "second genius" (178) a productive intellectual articulation is instigated. The agonistic approach of the controversy is important to maintain, to avoid a singular perspective, which seeks to dominate all value judgements. This speaks back to the productive cultures of liberalism highlighted in Chap. 1, a significant contrast to the vacuum of value in public discourse today.

Above all else, the two cultures controversy represents an embodied performance of disciplinary values. Leavis' response demonstrates a confident grasp of rhetorical tools and an ability to persuade an audience. It is a brazen example of "an alternative of [the kind of] reductive instrumentalism" (Collini, see Leavis 1962, 47) that Snow's vision of higher education represented. Collini argues that "infiltrating it [an alternative vision] into the critique of one's opponent's language, may be the only strategy for avoiding such vacuity" (48). Instead of speaking in abstract terms about the value of literary criticism, Leavis uses the form of the lecture to enact that value.

\subsubsection{The Two Cultures Today}

In contemporary higher education, such an oppositional relationship and attentiveness to rhetorical critique is wanting. Although the Snow-Leavis controversy is often regarded as a negative part of the history of higher education, I argue that a variety of diverse cultures is better than one unregulated market. Humanities scholars can return to the two cultures controversy through the printed legacy that was left behind. Although when transcribed, lectures lose many of their formal charms and confidences, these speeches continue to be significant. In 1995, Michael Caines cited Snow's The Two Cultures and the Scientific Revolution as one of the most influential books since World War II. ${ }^{11}$ The past five years has seen

${ }^{11}$ This list was published in The Times Literary Supplement (6 October 1995). 
increased media interest in reviving the debate between Snow and Leavis. ${ }^{12}$ This resurgence of interest correlates to the passing of the fiftieth anniversary of the debate. However, if the commemoration of the two cultures is simply to narrate its sequence, there seems little point in digging up the dirt. It is, therefore, beneficial to observe the formal qualities of the controversy, the rhetorical tools, and the potential for agonism.

Leavis' response presents a critique of language; in the present moment humanities scholars should equally attack the "leaden, cliché-ridden, overabstraction of so many official documents" and "the meaningless hype of advertising and marketing" (Collini, see Leavis 1962, 48). In the context of neoliberal monoculture, the existence of a multiplicity of voices and values is something worth fighting for, not about. In the present state of populism, in which inaccurate perspectives are held and shared without concern for veracity, we require critical voices that challenge the status quo. In his chapter in Gadamer's Repercussions, Richard Rorty optimistically envisions a future in which disciplinary differences are no longer seen as a weakness but as a strength:

every area of culture would be expected to have its own parochial description of every other area of culture, but nobody will ask which of these descriptions gets that area right. The important thing is that it will be herrschaftsfrei [free of domination]; there will be no one, overarching filing system into which everybody is expected to fit. $(2004,28)$

An academy that is herrschaftsfrei should be of interest to all scholars. Through conflicting discussion and through contest, comes intellectual cultivation.

\subsection{Part III: A Liberal Valuation: Arnold AND HuXley's EXCHANGE}

This section moves from a discussion about conflict into the realm of conversation. It is, nonetheless, not without some tension between scientific and cultural discourse. In Professions: Conversations on the Future of Literary and Cultural Studies (2001) Donald Hall describes how "conversations can take us places that we never imagined going. Unlike monologues multi-voiced discussions do not proceed according to any one individual's

${ }^{12}$ See Whelan, R. (2009); Collini, S. (2013); Bragg, M. (2013). 
plan; they develop [...] in surprising ways through chance occurrence and spontaneous articulation" (2001, 1). Matthew Arnold and Thomas Henry Huxley's exchange during the 1880s is a pronounced example of a "multivoiced discussion" (1) between science and literature. In the face of significant differences between their disciplinary approaches, Arnold and Huxley engaged in a conversation rather than a controversy. Although in both letters and public lectures, each is persuasive, they do not seek to shut out the possibility to consider another angle of the debate. While Snow and Leavis had no prior amicable relationship, Arnold and Huxley engaged in a long correspondence and shared belief in the value of a liberal education and the importance of fostering a richer cultural life in England. ${ }^{13}$

A sense of productive communication between the two men, as opposed to entrenched thinking, is captured in their correspondences. Walter Armytage's "Matthew Arnold and T. H. Huxley: Some New Letters 1870-80" (1953) provides valuable evidence of this mutual respect. For example, in a letter dated 17 October 1880, Arnold writes to Huxley: "God forbid that I should make such a bad return as to enter into controversy with you" (352 my italics). Attentiveness to the form of response and to the importance of speech-acts is not limited to Arnold's literary approach. Huxley was equally interested in expression and communication. His article "On Literary Style" concludes by citing Georges-Louis Leclerc de Buffon's dictum: "le style c'est l'homme" [the style is the man $].{ }^{14}$ The style of their conversation is considered and both Arnold and Huxley avoid being framed as omniscient.

\subsubsection{The Start of a Conversation}

On 14 June 1882 Arnold presented the annual Rede Lecture, "Science and Literature", at the very same occasion that Snow would introduce the concept of "the two cultures" some eighty years in the future. Whereas Snow's lecture initiated a debate, Arnold's lecture was a response. Arnold's speech was a formal answer to the renowned biologist, Huxley, who had

\footnotetext{
${ }^{13}$ These similarities between Arnold and Huxley include a common distrust in the truth claims of organised religion and a shared devotion to educational reform in England. Ortolano, G. (2009) draws similar attention to shared values between Snow and Leavis including meritocratic and broadly liberal views.

${ }^{14}$ Incidentally, Buffon was also a scientist interested in discursive style. He presented his "Discourse on Style" on being elected to the French Academy, 25 August 1753, in which he used the dictum "le style c'est l'homme même" [style is the man himself].
} 
presented his understanding of the relationship between "Science and Culture" two years prior, 1 October 1880, at the opening of Sir Josiah Mason's Science College in Birmingham. Huxley used this inauguration to argue that "the diffusion of thorough scientific education is an absolutely essential condition of industrial progress" $(1882,11)$. His lecture offers a history of the dominance of humanities disciplines and their traditional role as the guardians of culture. Huxley directly names his opposite, "Mr Arnold" (14) as the archetypal humanist scholar: "our chief apostle of culture" (14). Huxley introduces Arnold as an example of someone who has "true sympathy with scientific thought", and describes himself as "the last person to question the importance of genuine literary education, or to suppose that intellectual culture can be complete without it" (25). The tone of Huxley's reference to Arnold is very different to that of Leavis' attack on Snow or, indeed, Snow's comments about literary "Luddites" (1959b, 22). Directly naming Arnold is not framed as an attack but as an acknowledgement of his position as an advocate for humanistic study, and as an invitation for a response.

Communication and negotiation are at work in their exchange. The further relevance of style is evidenced by a significant part of Huxley and Arnold's exchange consisting of a clarification of vocabulary. How one expresses a point of view is of high importance. Throughout numerous letters, each continually concedes and appreciates the other's point of view and associated vocabulary. For instance, in a letter dated 17 October 1880 , Arnold explains that,

the dictum about knowing 'the best that has been known and said in the world' was meant to include knowing what has been said in science and art as well as letters. I remember changing the word said to the word uttered, because I was dissatisfied with the formula for seeming not to include art [...] however I went back to said for the base reason that the formula runs so much easier of the tongue with the shorter word. But I never doubted that the formula included science. (qtd. in Armytage 1953, 352 italic original)

Here, Arnold discusses the famous passage from Culture and Anarchy, in which he describes culture as the "pursuit of our total perfection by means of getting to know, on all the matters which most concern us, the best which has been thought and said in the world" $(1869,193)$. As the central tenet of his view of culture, and the function of criticism, one might assume that Arnold would be stubborn in acknowledging any fault with 
this conception. The above letter reveals how he is critically aware of the implications of language and remains adamant that science should be included in his broad definition of culture. This concession on Arnold's part reveals a deep concern for the critical analysis of language that remains at the heart of much humanistic study today. Arnold explains his language choice to Huxley with reference to rhetorical ease and a considered awareness of implicated meaning.

Irrespective of this aesthetic choice, which Arnold defends to Huxley, his 1882 Rede lecture makes an explicit concession in this regard. "I talk of knowing the best which has been thought and uttered in the world; Professor Huxley says this means knowing literature. Literature is a large word; it may mean everything written with letters or printed in a book" (220). Here we see the impact of cross-disciplinary conversation informing Arnold's expression with said being replaced by uttered as a gesture towards the inclusion of arts and science as discussed in the correspondence above. As Huxley named Arnold, so Arnold recognises Huxley. Despite its verbal inelegance, Arnold adopts 'utterance' to emphasise the diversity of mediated knowledge.

The desire for the correct rhetorical expression of the idea of 'culture' is a recurrent theme throughout Arnold's career. He even eventually came to feel the limitations of his famous dictum "sweetness and light". Small's The Value of the Humanities identifies how Arnold acknowledged the "frippery" $(2013,83)$ of the phrase in an address at the University of Liverpool, 30 September 1882. She traces the literary and philosophical allusions of "sweetness and light": observing that there is "too much packed into it by way of historical and intellectual argument" $(2013,86)$. However, Small emphasises one way in which the expression functions effectively as a descriptor of cultural value, arguing that "sweetness and light" "marks the place at which no terms will sustain their value for long as descriptors of certain things about culture which Arnold wants us to understand are valuable, but which depreciate as soon as they pass into a language of critical appreciation or evaluation" (86). In the pursuit of the right words, Arnold captures the striving towards values that lie beyond the limitations of linguistic category, something that articulations of value in the humanities strive towards.

However, this pursuit of value should not be understood as an exclusively humanistic trait. Rorty demonstrates how this is equally the case within the philosophy of science. He explains how: 
Gadamer once described the process of Horizontverschmelzung as what happens when 'the interpreter's own horizon is decisive, not as the standpoint of which he is convinced or which he insists on, but rather as a possible opinion he puts into play and at risk.' He [Gadamer] went on to describe this process as 'the consummatory moment of conversation [Vollzugsform des Gesprächs] in which something is expressed [eine Sache zum Ausdruck kommt] that is neither my property nor that of the author of the text I am interpreting, but is shared'. $(2004,29)$

This phrase is applicable to the exchange between Huxley and Arnold. The letters and lectures demonstrate a sense of playfulness with language and value, rather than treating them as part of a conflict. The aspiration towards that "consummatory moment of conversation" might not be fully realised, as the following section will evidence, however, each aspires towards a process of meaning-making that is shared. Their dialogue is not a contest of mutually exclusive opinions but rather represents a jostling for the immediacy of attention between literature and sciences. Rorty describes how this is different from the conflict of Snow-Leavis because such rivalry "would not be thought of as controversies about who is in touch with reality and who is still behind the veil of appearances. They would be struggles to capture the imagination, to get other people to use one's vocabulary" $(2004,28)$. Neither Arnold nor Huxley is 'right' or 'wrong', instead, they are engaged in a persuasion for their preferred vocabulary. It is the tone of their argument that is of principal interest. Huxley and Arnold's conversations, both in public and in private, clarify that there are two sets of ideas which cannot be fully aligned. However, each offers mutual respect and indicates a willingness to talk despite their disciplinary differences. Huxley describes how "the lesson of later life, is the renunciation of that encyclopaedic grasp the hope of which stirred the ambition of youth-and the resigning oneself to the conviction that in order to know one thing one must be content to be ignorant of thousands of things" ("On Literary Style" c.1890). That so much of their exchange concerns rhetoric demonstrates the significant value of precise and articulate language. Despite their diverse disciplinary expertise, each makes an effort to address areas where a fault is identified. Arnold continually insists on the value of the humanities in an increasingly technological world. Huxley wanted to forge a system of liberal education that included scientific discoveries in the physical sciences. However, the discussions between Arnold and Huxley do not mark a clear division between stasis and progress or 
between social knowledge and individual discovery. Instead, Arnold and Huxley are seen to subscribe to two alternative approaches to knowledge production that exists in harmony, reinforcing similar ends. The following section details how a common belief in liberal education enabled such considered and constructive correspondence.

\subsection{2 "Darwin's Bulldog” and "Our Chief Apostle of Culture"}

Although both Arnold and Huxley had specific motivations, their interest in the reform of education from primary through to higher education was a common goal, and they respected the benefits of each other's area of enquiry. Huxley was perhaps best known for coining the phrase 'Darwinism' and his career-long support of the evolutionary theorist earned him the nickname "Darwin's Bulldog". ${ }^{15}$ However, his aggression in defending Charles Darwin's theories of evolution does not reflect upon his manner in conducting conversations concerning the relationship between science and literature. In fact, in many ways, Darwin's $O n$ the Origin of Species (1859) contains aspirations of tolerance inherent in a liberal education. For example, in Darwinism, War and History (1994), Paul Crook argues that "literature has undervalued Darwinism's peace implications and especially Darwinism's capacity for assimilation into traditional value systems" (192). ${ }^{16}$ Within the harsh biological fabric of evolutionary theory, Darwin listed examples of social cooperation and repression of individual desires in order to benefit society, or civilizations, at large. In his famous chapter, "Natural Selection", in On the Origin of Species, Darwin notes how "in social animals it will adapt the structure of each individual for the benefit of the community; if each in consequence profits by the selected change" $(1859,84)$. Driver ants form a prominent example and Darwin suggests that "we can see how useful their production may have been to a social community of insects, on the same principle that the division of labour is useful to civilized man" $(1859,219)$. On the Origin of Species, a book at the forefront of scientific knowledge is connected to Arnold's efforts to promote self-cultivation as a means to a better society. The cultivation of a healthy "social community" (Darwin 1859,219 ) is recognised as being of benefit to the individual. This broadly encompasses the aspirations of science and the humanities alike: to provide

\footnotetext{
${ }^{15}$ See Huxley, T. (1860) 569.

${ }^{16}$ Further discussion of Crook's work on Darwinism can be found in Gagnier R. (2010) 15.
} 
a way for human beings, for humanity, to "profit by the selected change" (84). The precise means to "profit" (84) which Huxley and Arnold respectively favour may differ, but their general ambition is the same: the aspiration of these two eminent Victorians was the furtherance of a liberal education.

Arnold was relatively welcoming of the expansion of science within the university curricula. However, it must be acknowledged that Arnold's attempt to include science within culture only extended so far as science that was readily contained within literary forms. For example, Arnold discusses the importance of the written works of Isaac Newton's Principia (1687) and Euclid's Elements (c. 300 BC). In this sense, Arnold remains restrictive in his remit of culture, as he only accesses science through literature. The experience of culture, for Arnold, is found in what can be read and what is written, detached from live scientific processes, such as experimentation. Arnold's engagement with scientific knowledge was amateurish. As Fred Clarke recognises, it was a serious failure not "to realise that science was a necessary ingredient, growing in importance, of any conception of culture that could even then be called 'adequate"" (qtd. in Connell 1950, xv). In his defence, Dinah Birch contends that Arnold “didn't understand the development of scientific culture, as he simply never had the opportunity to encounter it" (qtd. in Bragg 2013). Arnold does not actively seek to disregard the value of the sciences, rather has a limited experience of it.

While Arnold avoided engaging directly with scientific knowledge he gestured towards their mutual benefit in "General Conclusion: School Studies" published in Schools and Universities on the Continent (1868): "he whose aptitudes carry him to the study of nature should have some notion of the humanities; he whose aptitudes carry him to the humanities should have some notion on the phenomena and laws of nature. Evidently, therefore the beginnings of a liberal culture should be the same for both" (300). ${ }^{17}$ This vision of liberal education includes both scientific and humanistic learning, not because they are different but because they can contribute to the same end. Both Arnold and Huxley recognised the importance of state intervention in education in order to achieve such

\footnotetext{
${ }^{17}$ These beginnings, for Arnold, include "the mother-tongue, the elements of Latin, and of the chief modern languages, the elements of history, of arithmetic and geometry, of geography, and of the knowledge of nature" $(1868,300)$.
} 
reform. Each frequently cited examples from universities in Germany and France as evidence of the successes of a liberal education. Arnold's $A$ French Eton (1864) presents his staunch belief in the successes of the French state intensive education programme in the development of lycée. In particular, Arnold celebrated "scientific instruction and the study of the mother-tongue which our school-course is without" (269). Praise of both science and modern literature demonstrates his awareness that educational improvement requires a broad range of disciplines. Although Arnold clearly cites the importance of scientific education, the "mother-tongue" (269) receives the greatest praise and critical attention. Arnold further records how the French "school-boy has a more real advantage over ours; he does certainly learn something of French language and literature" lamenting that "of the English, our schoolboy learns nothing" (270). Once more, Arnold's bias towards the value of the humanities is evident.

Huxley also urged for state intervention in education. Much like Arnold, his ideal was found in mainland Europe: "in Germany the universities are exactly what $[\ldots]$ the English universities are not $[\ldots]$ corporations of learned men devoting their lives to the cultivation of science" $(1868,107)$. The use of the word "cultivation" in reference to the sciences suggests an approach to learning that is focused on a rounded, rather than applied, education. Huxley's interest in Continental Europe also included praise of subjects beyond his personal investment in the physical sciences. In a letter published in the Pall Mall Gazette, 22 October 1891, Huxley insisted that "the works of our great English writers are preeminently worthy of being systematically studied in our schools and universities as literature" (301). Clearly, an echo of Arnold's A French Eton, such commentary reveals the cohesion in ideas between Arnold and Huxley despite their different backgrounds and principal interests.

\subsubsection{Articulating the Value of a Liberal Education}

The celebration of general cultivation and recognition of the benefits of multi-disciplinarity are clear indications of Huxley and Arnold's shared view of the value of a liberal education. The following quotation from Huxley's "Science and Culture" lecture, 1 October 1880, demonstrates some of the more complex relations to knowledge and culture that both Huxley and Arnold embraced. Huxley stated that:

I often wish that this phrase, 'applied science,' had never been invented. For it suggests that there is a sort of scientific knowledge of direct practical use, 
which can be studied apart from another sort of scientific knowledge, which is of no practical utility, and which is termed 'pure science'. [...] Applied science is nothing but the application of pure science to particular classes of problems. It consists of deductions from those general principles, established by reasoning and observation, which constitute pure science. No one can safely make these deductions until he has a firm grasp of the principles; and he can obtain that grasp only by personal experience of the operations of observation and of reasoning on which they are founded. (26)

In this passage, Huxley clarifies the value of "general principles" and challenges the idea that "applied sciences" are distinct from other scientific studies. Huxley is insistent that a firm grounding in pure scientific knowledge is required for all applied science. Much like Arnold, it is important for a scientist to grasp universally accepted knowledge, or "the best that has been thought and uttered in the world" $(1882,220)$, before making his own applied or practical contribution. Huxley's approach to describing the strength of science as distinct from utility seems a long way from the languages of STEM centre research outcomes in the 2010s. His words promote a pursuit of a knowledge base without specific utility and this semantic distinction from the present outcome-driven approaches is a significant linguistic (and social) leap.

As noted above, there are significant differences between Arnold's valuation of historical cultures and Huxley's appreciation of the general principles of physical science. Although both value non-instrumental forms of education, it is worth noting that a prerequisite of scientific knowledge is that it is continually falsifiable. Huxley observes that,

the notions of the beginning and the end of the world entertained by our forefathers are no longer credible [science] admits that all our interpretations of natural fact are more or less imperfect and symbolic, $[\ldots]$ it warns us that the assertion which outstrips evidence is not only a blunder but a crime. $(1880,22)$

This reliance on the physical truth that is 'nature' is in many ways the opposite of Arnold's 'culture' and remains a fundamental distinction between Huxley and Arnold's thinking throughout their exchange. As Gesche Ipsen et al. suggest, Arnold would likely add "the caveat that what matters to humans is truth among words as much as, if not more than, truth among things" $(2013,266)$. This difference in methodology is unresolved in the conversations, letters, and lectures of Arnold and Huxley. 
Despite their intention to speak to each other, not against one another, mutual misunderstandings leave a significant gap of incomprehension in their amicable exchange. Although their dialogue is imperfect, both Arnold and Huxley speak with a self-awareness of their own positions.

However, alongside differences, there are moments of recognition, or Horizontverschmelzung, (Gadamer's phrase for sharing horizons of intellect) which are worthy of reconsideration. For example, in a speech given at South London Working Men's College, 4 January 1868, Huxley maintained that "we must have History; treated not as a succession of battles and dynasties; not as a series of biographies; not as evidence that Providence has always been on the side of either Whigs or Tories; but as the development of man in times past, and in other conditions than our own" ("A Liberal Education" 1868, 109). To understand the development of humankind in this fashion and the significance of "other conditions than our own" does not deny the progress of science, but it does allow room for the valuation of the past. Such a statement offers hope that the value of the humanities might yet be understood not as a list, or a collection of dates, but as an active process of development and learning to understand others.

\subsubsection{Conclusion}

This chapter has reflected on the contemporary split between the humanities and STEM within policy by retracing two seminal exchanges between the sciences and the humanities. Although distinct in tone and historical context, both examples demonstrate the importance of how value is articulated. In these moments of public expression and contest, the way we argue (to borrow Anderson's excellent expression) is more important than what we are arguing about. How we choose to argue is a reflection, or as Anderson argues, an embodiment, of our values. Debate is both vibrant and malleable. Such attentiveness to the value of words that is evident in Arnold and Huxley's exchange, and the productive mutation of meaning through their letters and lectures provide a model for considered scholarly communication that should be acknowledged and admired. Despite their disciplinary biases both worked towards the promotion of a liberal education that, they believed, would support the development of curricula, and the general cultivation of individuals within universities and beyond. Their appeal to roundness stands in stark contrast to the applied and instrumental valuations that face contemporary higher education. 
Unfortunately, in many ways, the academy has inherited more from Snow and Leavis' debate than it has from Arnold and Huxley's exchange. The distinction between the two cultures continues to be produced, and re-produced, in a variety of ways. The systematic organisation of colleges within higher education institutions is one example; the coverage of artistic and scientific study in prescribed ways in the media is another. Just as Leavis enacted a close rhetorical dismissal of Snow's claims about the two cultures, so too should scholars be attentive to the ways in which the humanities are defined by those who are not qualified to speak for them. Although the use of language in the Snow-Leavis exchange is less constructive, I argue that it serves as an important example of styles of articulation in the creation of value. The form of the debate in public lectures reveals the power of an individual's voice to take control over "social event" (Collini, see Snow 1959b, xxviii). In the history of education, the importance of such speeches should not be overlooked. ${ }^{18}$

As suggested in Sect. 3.2, a concern about the two cultures of scientists and literary critics is not the most pressing concern in terms of contested sites of value within higher education. Instead, present antagonism comes from outside the academy, in the pressure of the monoculture of economic rationalism in policymaking that does not befit knowledge production in either sector. Huxley argued that "there is no more complete fallacy" $(1882,26)$ than the belief that applied skills need not rely on forms of pure science. Today, the government's support of specific kinds of STEM in light of their specific economic applications, represents a similar fallacy. There are numerous examples of how cuts to higher education budgets since 2008 have had an adverse effect on the sciences as well as the humanities. For example, in an open letter published in Nature, 8 October 2014, scientists affiliated with the organisation EuroScience state that:

despite what some politicians believe, applied research is unlikely to have much immediate impact on the market. Marketable research products are the low-hanging fruit of an intricate research tree, and undermining basic research will slowly kill the roots [scientific research] should not just serve the economy, but also aspire to increase knowledge. (Moro-Martín et al. 2014)

${ }^{18}$ Most famously, J.S. Mill's "Inaugural Address delivered to the University of St. Andrews" 1 February 1867. See also John Newman's Lectures, 1852 at the Catholic University in Ireland which were the basis of The Idea of a University, and John Ruskin's "Traffic", delivered in the Town Hall, Bradford, 1864. 
Attached to the open letter was a petition that, as of April 2018, 19,317 people had signed since 8 October 2014. The petition "They Have Chosen Ignorance" iterates clearly that "they" stands for the policymaker: "they have chosen to ignore that applied research is no more than the application of basic research and is not limited to research with short-term market impact" (Moro-Martín et al. 2018). The echoes of Huxley are strong in this petition, perhaps nowhere more so than in the closing sentence. The cultivation of individual education is not a redundant concern from the nineteenth century. Huxley concludes his 1880 lecture with the question: "if we could mould the fates to our own will" what kind of education "would [we] give our children?" $(1882,81)$. In a recapitulation of a liberal view of education, the scientists authoring this open letter "call on researchers and citizens to defend this position with us. [...] We owe it to our children, and to the children of our children" (Moro-Martín et al. 2014). If Huxley's question is still relevant, there might also be value in Arnold's response. In Culture and Anarchy, he argues that:

our poor culture, which is flouted as so unpractical, leads us to the very ideas capable of meeting the great want of our present embarrassed times! We want an authority, and we find nothing but jealous classes, checks, and a dead-lock; culture suggests the idea of the State. We find no basis for a firm State-power in our ordinary selves; culture suggests one to us in our best self. $(1869,99)$

Although universally unattainable under the present conditions of higher education, certain aspects of a liberal education remain useful as ideals. In "The Limbs of Osiris: Liberal Education in the English-Speaking World" (1993), Sheldon Rothblatt explores how the "ideal resembles an experiment $[\ldots$ which $]$ may or may not work in practice, but its value is in the trying and reaching" (70). This allows one to "explore alternatives and to exercise a creative reach in order to prevent human life from being overrun by the humdrum and banal" $(1993,70)$.

The potential of imaginative and fictional articulation of value will be explored in the subsequent chapter. In a move away from thinking only within the limits of economic policy, a turn towards expressive ideals offers an escape from "the humdrum and banal" (70). However, this is not only the task of the humanities: "there is, after all, a level at which science and literature begin with the same question: what if?" (Bigsby 2013). The sciences and the humanities must strive to coordinate their efforts across 
disciplinary distinctions in the current debate concerning value in higher education.

Twenty-five years after the two cultures debate, Thomas Pynchon argued that "today nobody could get away with making such a distinction" (1984). In 2007, Toby Miller reasserts a similarly utopic image where "young computer scientists are playing in the same virtual environments as young literary critics" (41). With increasing technical specialisation (databases, hypertext mark-up), the advent of digital practices (big data, distant reading), and collaboration (neurolinguistics, bio-ethics, cultural mapping) the humanities and the sciences are more often in conversation as opposed to conflict on an interpersonal level. Policymaking practices since the 1980s have suggested otherwise. In the languages and actions of policy, the two disciplinary groups are hierarchised. In this narrative, it becomes clear that today, the humanities and sciences are currently facing a greater adversary than one another. Whilst Small notes in the opening pages of The Value of the Humanities "there are clear and definitive differences between the kind of work pursued in the different faculties of universities" $(2013,4)$ these need not be perceived as being exclusively in conflict. In the preface to the first book edition of Culture and Anarchy, Arnold argues that "to convince those who mechanically serve some stock notion or operation" it is essential to "turn a free and fresh stream of thought upon the whole matter in question" $(1869,192)$. This chapter has identified how specific attentiveness to language has served the humanities in internal debates in higher education. It emphasises that the process of articulation and revision are natural aptitudes of the humanities. Chapter 4 questions whether or not such attention to reading, rhetoric, and the way the humanities are represented in fiction can be a productive site for further disrupting the external pressures and definitions regarding the value of the humanities.

\section{BIBLIOGRAPHY}

Anderson, Amanda. 2006. The Way We Argue Now. Oxford: Princeton University Press.

Armytage, Walter H. 1953. Matthew Arnold and T. H. Huxley: Some New Letters 1870-80. The Review of English Studies 4 (16): 346-353.

Arnold, Matthew. 1864. A French Eton. Democratic Education, Vol. 2 [1962], ed. R.H. Super, 262-326. Ann Arbor: University of Michigan Press. 
1868. General Conclusion - School Studies. In Schools and Universities on the Continent, Vol. 4, ed. R.H. Super, 1962: 289-302. Ann Arbor: University of Michigan Press.

- 1869. Culture and Anarchy. Reproduced in Culture and Anarchy and Other Writings, ed. Stefan Collini, 1993: 53-187. Cambridge: Cambridge University Press.

- 1882. Science and Literature: The 'Rede Lecture' 1882. The Nineteenth Century, delivered as the Rede Lecture August 1882.

Austin, John L. 1962. How to Do Things with Words. In The William James Lectures Delivered at Harvard University in 1955. Oxford: Oxford University Press.

Bigsby, Christopher. 2013. Art and Science: 'Two Cultures' with Shared Values. Times Higher Education Online, December 12. Accessed 3 Apr 2017, via www. timeshighereducation.com/comment/columnists/art-and-science-two-cultures-with-shared-values /2009746.article

Bragg, Melyvn. 2013. Two Cultures. The Value of Culture Series, January 2. Cambridge: BBC Radio 4.

British Academy. 2010. Past, Present, and Future: The Public Value of the Humanities and Social Sciences. British Academy, June. Accessed 12 Aug 2017, via www. britac.ac.uk/past-present-and-future-public-value-humanities-and-social-sciences

Browne, John (Lord Browne of Madingley). [The Browne Report] 2010. Securing a Sustainable Future for Higher Education: An Independent Review of Higher Education Funding and Student Finance. October 12. London: BIS. Available at: www.gov.uk/Government/publications/the-brownereport-higher-educationfunding-and-student-finance

Butler, Judith. 2010. Performative Agency. Journal of Cultural Economy 3 (2): 147-161.

Caines, Michael. 1995. The Hundred Most Influential Books Since the War? The Times Literary Supplement, October 7 . Accessed 12 Oct 2015, via www.the-tls. co.uk/the-hundred-most-influential-books-since-the-war/

Collini, Stefan. 2012. What Are Universities for? London: Penguin.

- 2013. Leavis v Snow: The Two-Cultures Bust-Up 50 Years on. The Guardian, August 16. Accessed 21 Nov 2013, via www.theguardian.com/ books/2013/aug/16/leavis-snow-two-cultures-bust

Connell, William F. 1950. Educational Thought and Influence of Matthew Arnold. Westport: Greenwood Press.

Crook, Paul. 1994. Darwinism, War and History. Cambridge: Cambridge University Press.

Darwin, Charles. 1859. On the Origin of Species. Available Through A Penn State Electronic Classics Series Publication. Accessed 24 Dec 2013, via www2.hn.psu. edu/faculty/jmanis/darwin/originspecies.pdf

Editors of the Lingua Franca. 2000. The Sokal Hoax: The Sham That Shook the Academy. Lincoln: University of Nebraska Press. 
Encounter. 1959a. C. P. Snow and 'The Two Cultures'. Encounter, August, 67-73. 1959b. The Two Cultures. Encounter, September, 61-65.

Furedi, Frank, Roger Kimball, Raymond Tallis, and Robert Whelan. 2009. From Two Cultures to No Culture C.P. Snow's 'Two Cultures' Lecture Fifty Years On. London: Civitas.

Gagnier, Regenia. 2010. Individualism, Decadence and Globalization: On the Relationship of the Part to the Whole. Basingstoke: Palgrave Macmillan.

Hall, Donald E. 2001. The Functions and Dysfunctions of Criticism at the Present Time. In Professions: Conversations on the Future of Literary and Cultural Studies, ed. Donald E. Hall, 1-20. Chicago: University of Illinois.

Huxley, Thomas Henry. 1860. Darwin on the Origin of Species. Westminster Review 17: 541-570.

-1868. A Liberal Education: And Where to Find It. In Science \& Education, Huxley's Collected Essays, Volume III, 76-110. London: Macmillan and Co.

- 1880. Science and Culture. Science and Culture and Other Essays [1882]. London: D. Appleton and Company.

- c.1890. On Literary Style. Unpublished Essay. The Huxley File, created by Charles Blinderman and David Joyce. Accessed via mathcs.clarku.edu/huxley/ Mss/Litstyle.html

- 1891. Letter on University Education. Pall Mall Gazette, October 22. Reproduced in Life and Letters of Thomas Henry Huxley, vol. 2. Accessed via mathcs.clarku.edu/huxley/UnColl/PMG/PMGetal/UnivEd.html

Ipsen, Gesche, et al. 2013. Provocation and Negotiation: Essays in Comparative Criticism. Amsterdam: Rodopi.

James, Frank. 2016. Introduction: Some Significances of the Two Cultures Debate. Interdisciplinary Science Reviews 41 (2-3): 107-117.

Kagan, Jerome. 2009. The Three Cultures: Natural Sciences, Social Sciences and the Humanities in the 21st Century. Cambridge: Cambridge University Press.

Kimball, Roger. 1994. 'The Two Cultures' Today. The New Criterion 12 (6): 10. Leavis, Frank R. 1962. The Two Cultures? The Significance of C. P. Snow. With Introduction by Stefan Collini. The Two Cultures? The Significance of C. P. Snow. Reprinted Canto Edition [2013]. Cambridge: Cambridge University Press.

Mill, John Stuart. 1867. Inaugural Address Delivered to the University of St Andrews. Collected Works of John Stuart Mill, Vol. 21. [1984], ed. John M. Robson. Toronto: University of Toronto Press.

Miller, Toby. 2007. Can Natural Luddites Make Things Explode or Travel Faster? In MyCreativity Reader: A Critique of Creative Industries, ed. Geertz Lovink and Ned Rossiter, 41-48. Amsterdam: Institute of Network Cultures.

Moro-Martín, Amaya et al. 2014. A Call to Those Who Care About Europe's Science. Nature 514 (7521): 141.

. 2018. They Have Chosen Ignorance. EuroScience Online. Accessed 2 Jan 2018, via openletter.euroscience.org/open-letter/ 
Newman, John. 1852. Discourse 5. Knowledge Its Own End. The Idea of a University. Accessed 2 Apr 2015, via www.newmanreader.org/works/idea/ discourse 5.html

Nietzsche, Friedrich. 2006. Homer's Contest. In On the Genealogy of Morality and Other Writings, ed. Keith Ansell-Pearson and Trans. Carol Diethe, 174-182. Cambridge: Cambridge University Press.

Nussbaum, Martha C. 2010. Not for Profit: Why Democracy Needs the Humanities. London: Princeton University Press.

Ortolano, Guy. 2009. The Two Cultures Controversy: Science, Literature and Cultural Politics in Postwar Britain. Cambridge: Cambridge University Press.

Pynchon, Thomas. 1984. Is It OK to Be a Luddite? The New York Times, October 28. Accessed 3 Apr 2017, via archive.nytimes.com/www.nytimes.com/ books/97/05/18/reviews/pynchon-luddite.html?

Rorty, Richard. 2004. Being That Can Be Understood Is Language. In Gadamer's Repercussions: Reconsidering Philosophical Hermeneutics, ed. Bruce Krajewski. Berkeley: University of California Press.

Rothblatt, Sheldon. 1993. The Limbs of Osiris: Liberal Education in the EnglishSpeaking World. In The European and American University Since 1800, ed. Sheldon Rothblatt and Bjorn Wittrock, 19-73. Cambridge: Cambridge University Press.

Ruskin, John. 1864. Traffic. Reprint 2015. London: Penguin Classics.

Schama, Simon. 2011. Cuts Will Make History Preserve of the Rich. The Telegraph, February 20. Accessed 12 June 2017, via www.telegraph.co.uk/education/ educationnews /8336498/Simon-Schama-cuts-will-make-history-preserve-ofthe-rich.html

Sleigh, Charlotte. 2011. Science and Literature. Basingstoke: Palgrave Macmillan. Small, Helen. 2013. The Value of the Humanities. Oxford: Oxford University Press. Snow, Charles Percy. 1959a. The Two Cultures. New Statesman, October 2. Accessed 10 Dec 2014, via www.newstatesman.com/cultural-capital/2013/ $01 / \mathrm{c}$-p-snow-two-cultures

- 1959b. The Two Cultures, Rede Lecture 1959. With Introduction by Stefan Collini. The Two Cultures. Reprinted Canto edition [2012]. Cambridge: Cambridge University Press.

Sokal, Alan. 1996. Transgressing the Boundaries: Towards a Transformative Hermeneutics of Quantum Gravity. Social Text 46-47: 217-252.

Stern, Nicholas. [The Stern Report] 2016. Building on Success and Learning from Experience an Independent Review of the Research Excellence Framework. London: HMSO.

Stringer, Peter. 1983. C. P. Snow's Fiction of Two Cultures. In Special Issue: Psychology and the Arts, Leonardo, 16 (3): 172-176.

Syntax. 1825. Letter to the Editor. The Times, November 18, 4. 
The Spectator. 1962. Sir Charles Snow, Dr. F. R. Leavis, and the Two Cultures. Letters to the Spectator, March 16, 9-15.

Trilling, Lionel. 1962. Science, Literature and Culture: A Comment on the LeavisSnow Controversy. Higher Education Quarterly 17 (1): 9-32.

University of Exeter. 2013a. A Year in the Life of the University of Exeter. University of Exeter YouTube Channel, December 12. Accessed via www.youtube.com/ watch?v=SglbecGxJRc

- 2013b. Buoyant Bronze Age Boat Makes History in Cornwall. University of Exeter Featured Alumni News Website, March 6. Accessed via www.exeter. ac.uk/alumnisupporters/news/featurednews/title_271848_en.html

Waugh, Patricia. 2009. Review of the Two Cultures Controversy: Science, Literature and Cultural Politics in Postwar Britain. Reviews in History (Review No. 849): 308.

Whelan, Robert. 2009. Fifty Years On, CP Snow's 'Two Cultures' Are United in Desperation. The Telegraph, May 5. Accessed 12 May 2015, via www.telegraph. co.uk/technology/5273453/Fifty-years-on-CP-Snows-Two-Cultures-areunited-in-desperation.html

Open Access This chapter is licensed under the terms of the Creative Commons Attribution 4.0 International License (http://creativecommons.org/licenses/ by $/ 4.0 /$ ), which permits use, sharing, adaptation, distribution and reproduction in any medium or format, as long as you give appropriate credit to the original author(s) and the source, provide a link to the Creative Commons licence and indicate if changes were made.

The images or other third party material in this chapter are included in the chapter's Creative Commons licence, unless indicated otherwise in a credit line to the material. If material is not included in the chapter's Creative Commons licence and your intended use is not permitted by statutory regulation or exceeds the permitted use, you will need to obtain permission directly from the copyright holder.

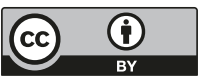

